\title{
The politics of ageing: health consumers, markets and hegemonic challenge
}

\section{Introduction}

Writing in The Times two days after the UK's EU Referendum and the Leave victory, the columnist and Remain supporter Giles Coren (48) said,

The wrinkly bastards stitched us young 'uns up good and proper on Thursday. From their stairlifts and their zimmerframes, their electric recliner beds and their walk-in baths, they reached out with their wizened old writing hands to make their wobbly crosses and screwed their children and their children's children for a thousand generations (Coren 2016: 28).

In recent years ageing has travelled from the placid backwaters of politics into the mainstream of policy debate. Accompanying that voyage has been a steady increase in the visibility of age-related issues such as intergenerational justice, age discrimination, the power of the 'grey pound' and 'grey vote', pension and mortgage market changes, and, inevitably, NHS costs. Debates surrounding ageing regularly span the social, the economic and the political, on the one hand, and a range of age groups, on the other. New narratives of ageing have emerged with the language of 'opportunity' and 'potential' challenging the traditional discourse of 'decline' and 'deficit' expressed so viscerally by Coren.

How and why has this happened? What are the forces that have politicised ageing across such various dimensions, creating a sustained opposition to the established institutions which, historically, have constructed, propagated and legitimised our understanding of ageing? In addressing these questions this paper applies an analysis drawing on the work of Gramsci as a platform for the exploration of the engagement between the hegemonic and counter-hegemonic dynamics of ageing. Ageing is seen as a political terrain where there is a continuing struggle for advantage between traditional and emergent forms of power. What was once a peaceful territory dominated by a hegemonic view of ageing as an inevitable 
process of biological, economic and cultural decline has become one characterised by tensions and contest. Whilst accepting there is a foundational aspect to ageing that embodies physical disability and ultimately death (Gilleard \& Higgs, 2000), alternative, positive interpretations of the life course and the transitions it embodies have challenged both the hegemonicideology of ageing itself and its economic and institutional infrastructure.

Whilst accepting Gramci's view regarding the importance of the economic base in shaping the sources of hegemonic challenge, the paper expands that perspective to include the potentially disruptive power of consumers and markets. Rather than markets being assumed to be an integral part of a hegemony supportive of a particular power alliance, the issue is left open: some markets will be but some may not. Consumers may choose to express their demand outside the borders of the hegemonic markets and new markets may emerge in response to, or anticipation of, this demand. Individuals acting in concert through the mechanisms of the market, and not institutionalised modes of opposition, may become the agents of hegemonic challenge. The causal primacy of the economic base is thus retained, but not in the form Gramsci would have construed it. At the same time, rather than viewing it as a quality attached to particular groups in the chronology of life, ageing is seen as a continuum of movement over time through changing social and economic contexts where politicisation of ageing may occur.

The paper begins by elaborating a Gramscian approach to the politics of ageing and progressively applies it to the institutions, ideology and modus operandi of the hegemony itself. What power interests are served by the hegemony, how does it work, and what tensions does it embody? Second, the rise of the counter-hegemony of ageing is analysed focusing in particular on the political and ideological implications of market power and consumer choice. In what ways do market-based forms of consumer power challenge the hegemony of ageing through the operation of disruptive capitalism? What new forms of social relations does the counter-hegemony generate and to what extent are they sustainable as an oppositional force? 


\section{Hegemony and ageing}

In its traditional form, the hegemony of ageing presents the latter stages of the life course as a journey of decline where the loss of economic, social and cultural value is the inevitable individual experience. Who benefits from this view? Driving any hegemony is what Gramsci terms the blocco storico, the historic block, acting to construct and justify its power. More than simply a political alliance between social forces, the blocco storico integrates and propagates a set of interests 'bringing about not only a unison of economicand political aims, but also intellectual and moral unity ... on a "universal" plane' (Gramsci, 1971: 181-2). This unity is achieved through the propagation of an ideology and the maintenance of a cultural hegemony expressed in terms of: 'Consent given by the great masses of the population to the general direction imposed on social life by the dominant fundamental group; this consent is "historically" caused by the prestige (and consequent confidence) which the dominant group enjoys because of its position and function in the world of production.' (Gramsci, 1971: 145) In order to acquire and maintain the consent of their subject population through ideological domination, hegemonies 'must propose a set of descriptions of the world, and the values that preside over it, that become in large measure internalised by those under its sway' (Anderson, 2017: 21). In its most developed form, hegemony creates 'an order in which a certain way of life and thought is dominant, in which one concept of reality is diffused throughout society in all its institutional and private manifestations, informing with its spirit all taste, morality, customs, religious and political principles, and all social relations, particularly in their intellectual and moral connotation' (Williams, 1960, 587). In other words, 'hegemony is soft power, the ability to make others want the same thing as yourself, as distinct from hard power, the ability to force others to give you what you want' (Wade, 2002, 216).

In the case of ageing, this paper argues that the historic block is composed of the pharmaceutical industry, the medical profession and the state. Through an established and interlinked network of institutions described in detail in work on the 'health care state' in the United Kingdom (UK) (Moran, 1999) and the medical-industrial complex in the United 
States (US) (Estes, 1986; Relman, 1980; Wohl, 1984), the block works to control the health care market, its supporting system of social relations and the values necessary to maintain the hegemonic distribution of benefits and power to the block members. As Estes has elaborated, these members combine to constitute the 'ageing enterprise' composed of the 'programmes, organisations, bureaucracies, interest groups, trade associations, providers, industries, and professionals that serve the aged in one capacity or another' (Estes, 1979: 2). Essentially the block is a supply-side hegemony, working to maintain a view of ageing that will generate a predictable and increasing health care demand to service the current and future supply from its economic base, the pharmaceuticals. Earlier research on the political economy of ageing emphasised the labour market dimension of the economic base in terms of the exclusion of older people from employment through the social process of retirement, their redefinition as 'old age pensioners' in terms of income, and their labelling as 'old and needy' in terms of social policy (Phillipson, 1982; Walker, 1981). Poverty and dependence were seen to be a necessary consequence of that subordination to the requirement of the capitalist economy for a flexible pool of labour (Phillipson, 1998; Walker, 1980). In this paper the emphasis is much more on the dynamic of the pharmaceutical industry where older people are still conceived of as 'old and needy' in order to stimulate and justify demand for drugs but, importantly, may also be active pharmaceutical consumers responding to that demand with income generated through employment. In this context the needs of the labour market are less important than the need of the pharmaceutical industry for expanding demand - be this from the state or from citizens themselves.

\section{Economic base}

In global terms, the success of the hegemony is evident in the continuing expansion of its economic base. By 2018, world spending on medicines is forecast to reach nearly $\$ 1.3$ trillion, an increase of about 30\% over the 2013 level representing a compound annual growth rate of $4.7 \%$ on a constant currency basis. Whilst the developed markets of the United States, Europe and Japan are currently the primary drivers of this growth, the global reach of the hegemony is reflected in the predicted pharmaceutical market growth of emerging economies such as China and India of 8-11\% up to 2018 (IMS Institute of 
Healthcare Informatics, 2014, 1). Between 1972 and 2005 the global drugs bill increased thirty fold (Law 2006). In England alone, the dispensing of prescription drugs has increased by almost $60 \%$ in the past ten years, with the average annual number of prescription items per head rising from 13 in 2003 to 19 in 2013 (Health and Social Care information Centre, 2014a). The Health Survey for England 2013 reported that $43 \%$ of men and 50\% of women had taken at least one prescribed medicine in the last week (Health and Social Care Information Centre 2014b: 11). Importantly, as age increases so does drug consumption, in part as a result of increasing co-morbidities. Research in England on polypharmacy (five or more drugs simultaneously prescribed) showed it to be clearly age-related. For example, between 1995 and 2010 the proportion of people aged 65 and over who were dispensed 5 or more drugs increased from $11.4 \%$ to $20.8 \%$ (Guthrie et al, 3). Similarly in the US, between 1988-1994 and 2013-2014, the percent of adults reporting the use of five or more prescription drugs in the past 30 days rose - by $2.7 \%$ for adults aged $18-44,12.8 \%$ for adults aged $45-64$, and $28.4 \%$ for adults aged 65 and over (National Centre for Health Statistics, 2016: 25). The case of statins to reduce cholesterol in older people is particularly illustrative of this trend with UK prescriptions for Atorvastatin rising $42 \%$ from 12.8 million items in 2012 to 18.2 million items in 2013 (Health and Social Care Information Centre, 2014a). A table from the Health Survey for England 2013 provides a graphic portrayal of the overall age-drug consumption relationship (Table 1) (Health and Social Care Information Centre 2014b: 11). Ageing and the continued expansion of the pharmaceutical industry are inextricably linked. 
Table 1

Age and the consumption of prescribed medicines (2013)

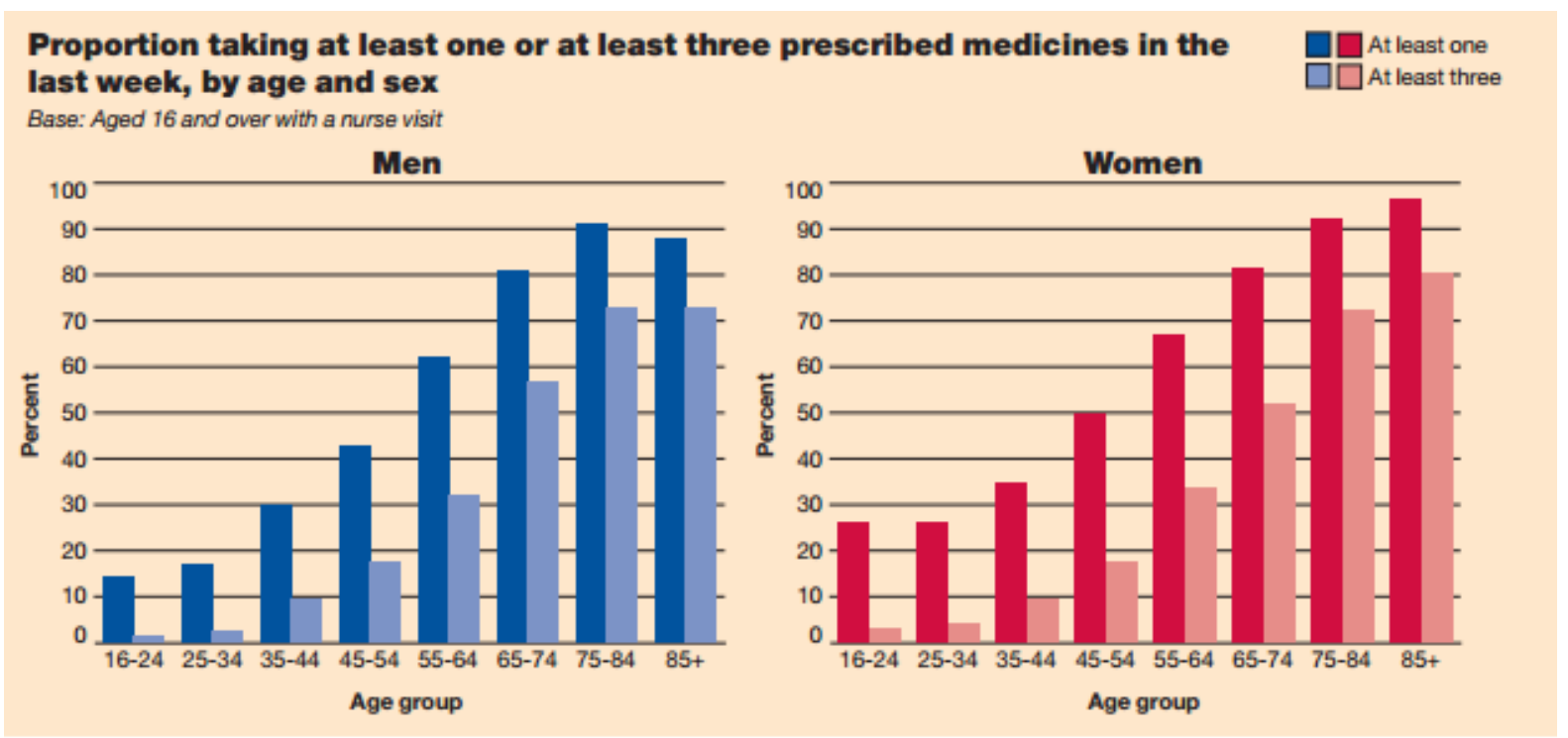

These are impressive figures, reflecting the fact that the drug industry is one of the world's largest. How does the hegemony act to sustain the dominant position of its economic base over time, consistently seeking to shape consumer demand through the construction of appropriate social relations of production? Williams et al have charted what they term the 'pharmaceuticalisation of society' characterised by 'the translation or transformation of human conditions, capabilities and capacities into opportunities for pharmaceutical intervention' (Williams et al, 2011, 711). It is presented as a process which is value-neutral, 'may include both gains and losses to socie ty' and be partial or complete (Williams et al, 2011: 719). Pharmaceuticals are seen as engaging in the 'corporate construction of disease', where the ambition is to turn ordinary ailments into medical problems, presenting mild symptoms as serious, treating personal problems as medical and risks as diseases (Moynihan, 2002). In its constant search for new consumer markets, the industry promotes 
the utility of biomedical enhancement through its advancement of socially expected standards of normality, bodily augmentation and rejuvenation (Conrad, 2007, 87-9; Salter, Howe, McDaid et al, 2011:809). Ultimately its goal is what Fox and Ward describe as 'the pharmaceuticalisation of everyday life' where drugs become the accepted answer to the common problems of daily living (Fox and Ward, 2009). In this perhaps not so distant future where everyday life has been 'colonised by pharmaceutical solutions' (Williams et al, 2009, 721), the hegemonic capture of consumer demand would then be complete.

The extent to which such market dominance is either achievable or sustainable rests not just on the efforts of the pharmaceutical industry but on the ability of the blocco storico as a whole to support and legitimise the evolving nature of its economic base. As Williams et al note, 'there are important sources of resistance to the expansion of pharmaceutical markets from the media, government, medicine, patients and diverse publics' (Williams et al, 2011: 722). It is therefore important that medicine and the state combine to foster the social relations congruent with the operation of the hegemonic pharmaceutical market. Medical authority, firstly, has traditionally been employed to control and structure consumer demand for health treatment by defining it in terms of 'clinical need'. At the same time, in acting as the gatekeeper to medicines the profession is naturally interested in expanding its own territory as well as that of the pharmaceutical industry (Busfield, 2010). Often working in tandem with the latter, medicine pursues its own path of what has been termed 'medicalisation' characterised by 'defining a problem in medical terms, usually an illness or disorder, or using a medical intervention to prevent it' (Conrad, 2005: 3; see also Ballard and Elston, 2005). For example, problem gambling has recently been defined as an addiction requiring pharmaceutical treatment (Ellison, 2016). As with pharmaceuticalisation, 'in the sea of medicalisation there are some islands of resistance....such as homosexuality and disability [which] politicise the issue and make it part of the agenda of a social movement' (Conrad, 2007: 161). Nonetheless, in general medicalisation allows the profession to use its power of diagnosis as the means for massaging and justifying new patient expectations and, as a result, fresh consumer demand for pharmaceutical products. In so doing the profession is enabling a hegemonic infrastructure of production which 'covers the production and reproduction of knowledge and of the social relations, morals and institutions that are 
prerequisites to the production of physical goods' (Cox, 1987, 4) - in this case pharmaceutical goods. Medicalisation and pharmaceuticalisation can thus be seen as complementary functions carried out to their mutual benefit by two partners of the historic bloc. For the health consumer, the implication of the partnership is that individual consumer choices are not only framed by the drug industry and guided by medical expertise but also made in the context of hegemonic social values propagated by the partnership. As Dew et al have shown, self-governance in the use of drugs is subject to the pervasive, but not necessarily effective pressure of hegemonic moral discourses to which consumers may or may not be resistant depending, as we shall see later, on their ability to draw on alternative discourses embodying a counter-hegemonic form of demand (Dew et al, 2015).

With the pharmaceutical industry and medical profession allied through their management of a mutually beneficial hegemonic market, an important political task of the third partner in the blocco storico, the state, is the institutional facilitation of this particular form of production. In his work on the health care state, Moran charts the 'interpenetration of the institutions of the state and the institutions of the health care system' and shows how the resources of the democratic state offer the medical profession the opportunity to gain competitive advantage in healthcare markets by securing preferential policy outcomes in, for example, the implementation of restrictive practices (Moran, 1999, 10, 14). It is not a one-way transfer of benefits. Salter's research documents how the medicine-state concordat provides medicine with the institutions of self-regulation, status and power and the state with a key mechanism in the political management of the health service: the rationing by the medical profession of the health service demand generated by citizens' health care rights, (Salter, 2004). Like most partnerships it has periods when tensions and disagreements come to the fore: for example, the extended dispute in 2016 over junior doctor contracts. But the institutional arrangements governing the medicine-state relationship remain unchallenged and ensure that the negotiation of the exchange of benefits between the three partners of the blocco storico is a key element in its overall stability. 
For the pharmaceutical-state relationship this takes the form of a common interest in the economic health of the industry. A key institutional role in the alliance is that of the regulatory agency. Commonly funded by the industry itself, in the main as a result of the neo-liberal impulse which influenced many Western modes of governance from the 1980s onwards, and legally sanctioned by the state, the agency is tasked with balancing the needs of public health with those of the industry. The hegemonic imperative to maintain and increase pharmaceutical consumption renders this a difficult task. Research has revealed evidence of a corporate bias and privileged access by pharmaceutical companies to regulatory bodies such as the Food and Drug Administration (FDA) in the USA and the Medicine and Health Care Products Regulatory Agency (MHRA) in the UK amounting to a 'regulatory capture' likely to diminish the weight given to the publichealth interest (Abraham 2009a; Abraham and Lewis, 2002). Policies designed to facilitate the arrival of new products on the market have produced significant reductions in the regulatory review times for new patentable drugs, reducing them by half in the USA since 1993 with similar falls evident in Europe (Abraham 2009b: 60). Internationally, agencies compete with one another to produce modes of regulation that can generate faster and more efficient drug innovation as they respond to the pressures of the global pharmaceutical market, thus locking them into the pharmaceutical-state section of the hegemony (Williams et al, 2011: 714).

\section{Ideology and legitimation}

The sustainability of the hegemony through the activities of the blocco storico is dependent not only on the interwoven interests and institutions of its constituent partners but als o the propagation of a belief system capable of legitimising that arrangement as an expression of the economic base. Gramsci is clear about the interdependence of base and superstructure arguing that 'the material forces would be inconceivable historically without form and ideologies would be individual fancies without the material forces' (Gramsci, 1971: 377). Their synthesis is achieved, he maintains, by 'widening a theory of the state to include relations within civil society' in order to understand the way in which hegemony acts to generate consent (Beiler and Morton, 2003). By extending the concept of the state beyond the formal apparatus of government to include important elements of the private sphere of 
society, Gramsci provides the analytical path for showing how the historic bloc acts to universalise the norms and values consistent with its economic base, bringing together state power and the underlying configurations of social forces (Germain and Kenny (1998: 15). How does this process work in the hegemony of ageing?

Pharmaceuticalised ageing is a central feature of the hegemony's economic base: increased age brings increased drug consumption. To sustain this market characteristic, consumer demand is controlled through an ideological narrative of decline. What the World Health Organisation (WHO) has described as 'deficit conceptualisations' of ageing present it as characterised by increasing vulnerability, exposure to risk and social disengagement (WHO, 2015: 8). Such 'ageism' has been defined by Bytheway and Johnson as,

a set of beliefs ... relating to the ageing process. Ageism generates and reinforces a fear and denigration of the ageing process, and stereotyping presumptions regarding competence and the need for protection. In particular, ageism legitimates the use of chronological age to mark out classes of people who are systematically denied resources and opportunities that others enjoy, and who suffer the consequences of such denigration, ranging from well-meaning patronage to unambiguous vilification (Bytheway and Johnson 1990: 28).

The prevalence of the ideology is evident in the extent to which it is ingrained in social views of ageing. Negative ageist attitudes are widely held and not confined to one social or ethnic group (Kite and Wagner, 2002). As one would expect within an effective hegemony, such ageism is regarded as legitimate and, in Allen's view, 'is one of the most socially condoned and institutionalised forms of prejudice....generally considered normative and acceptable', unlike, say, racism and sexism (Allen, 2015).

The impact of the decline ideology is evident at the micro-level of individual reality, the mesa-levels of the Health Service and biomedical research and the macro-level of policy. From this perspective, as people age so they are more likely to be 'not healthy', 'ill' and deviant, with a consequent reduction in their social value (Dew et al, 2015: 272). As the 
WHO observes 'decline and increasing irrelevance appear inevitable, and decision-makers focus on the "care of the elderly" and fret over what is portrayed as dependence and increasing demands for health care, pensions and social services' (WHO 2015: 8).

Retirement is taken to symbolise a more general process of social withdrawal and gradual shedding of social identity that necessarily accompanies ageing (Gilleard and Higgs 2000: 32). With withdrawal comes a dependency structured and institutionalised by the state: individuals are seen to have a social deficit for which the state must compensate, with social dependency the consequence (Townsend 1986: 21). With increasing age people are pressurised to accept the implications of their diminishing worth. Olderadults who internalise ageist beliefs can behave as though they are no longer independent and healthy (Levy 2009). Exposed to negative age sterotypes in laboratory studies, they demonstrated worse memory, handwriting and self-confidence and appeared to age instantly- moving in a stereotypically older manner (Meisner, 2012). Such stereotype embodiment has been shown to decrease the mental health, well-being and will to live of older adults (Wurm and Benyamini 2104).

Health and social care services routinely implement the decline ideology in their procedures, decision making and professional values, institutionalising age discrimination in all areas of service provision (Lloyd-Sherlock et al, 2015). Studies regularly document the established relationship between increasing age and the decreasing quality of health care received in secondary care (eg oncology, heart disease, neurology), primary care (eg osteoarthritis, screening) and mental health services (Clark 2009; Centre for Policy on Ageing 2009). Health professionals customarily discriminate on the basis of age. For example, in the treatment of cardiovascular disease, a study found that 46 per cent of GPs and 49 percent of cardiologists treated patients over 65 less well than those under 65 (Harries et al 2007). Behind the behaviourlies the attitude. A survey of oncology healthcare professionals reported that regardless of gender, profession and clinical experience persistently negative attitudes were displayed towards elderly people (Kearney et al 2000). In a survey of 870 family and hospital doctors, one in three felt care should be limited on age grounds and that elderly patients should not be given free treatment if it were unlike ly to do them good for long (Donnelly 2008). Such data fits readily with the hegemonic view that social value 
declines with age, that health care rights of citizens should diminish accordingly and that the age-based rationing of health care supply is therefore rational and legitimate. One prominent technical tool use by the National Institute for Health and Clinical Excellence (NICE) to judge the cost-effectiveness of health interventions in the NHS as a means for resource allocation, the QALY (Quality Adjusted Life Year), faithfully reflects and reinforces this philosophy. The olderyou are the fewer the QALYs you are likely to generate, the smaller the value accrued from your treatment and therefore the less justification for investment in your health: a measure which Harris describes as 'inherently ageist' (Harris 2005: 374). Similarly in health research, clinical trials have routinely excluded older participants or those with comorbidities meaning that the drugs produced are often not able to be prescribed to older populations (see eg Rajapakse et al 2008). Such is the power of the ideology that older patients frequently accept its logic and are prepared to self-ration in favour of younger people. A survey of over-65s hypothetically about to receive cardiac surgery found that 37 percent of respondents would be willing to swap places with a younger person six months behind on the waiting list (Bowling et al 2002). Internalisation of a hegemony's values by those it oppresses is a key indicator of hegemonic success.

\section{The emerging counter-hegemony}

Ensconced in the protective embrace of the blocco storico of pharmaceuticals, medicine and health care state, the hegemonic ideology of ageing promotes a continuum of social value where worth diminishes with advancing age. Supply side driven by an expanding global economic dynamic, the hegemony appears secure. How, then, has opposition emerged? Gramsci's theory suggests that a counter-hegemony may be mobilised through a 'war of position' which 'slowly builds up the strength of the social foundations of a new state' by 'creating alternative institutions and al ternative intellectual resources within existing society' (Cox, 1983:165). Ideologically based, the opposing forces are essentially cultural, driven by organic intellectuals who construct and organise a counter-hegemonic consciousness capable of sustaining an alternative reality to that promoted by the hegemony (Gramsci, 1971: 328-41). The economic base, meanwhile, is seen to play little direct part in the hegemonic struggle. The focus is on the nexus between civil society and state. In contrast, the argument of this paper is that in the case of the hegemony of ageing 
the economic base is central to an understanding of how opposition has arisen, an alternative ideology of ageing has developed, and new cultural forms have become legitimate.

\section{Economic base}

The objective of the blocco storico is to sustain and enhance the operation of the pharmaceutical market. This it does. Where it has problems is in the prevention of the emergence of other markets, not directly in competition with the pharmaceutical market, where the exercise of consumer demand over time generates an alternative ideology of ageing. As Moran observes in his work on the health care state, 'the impact of capitalist competition is destabilisation' and 'a constant source of disturbance to any momentary institutional equilibrium reached for the government of consumption, professions or production' (Moran, 1999: 13). What is the dynamic that has fuelled this destabilisation in the case of ageing?

The hegemony of ageing assumes that economic decline will accompany political, social and cultural decline as an individual progressively moves to the margins of society. The evidence of the last forty years suggests that the opposite has happened and that ageing is accompanied by the steady acquisition of economic resources: resources that may be used to stimulate the emergence of new markets and new identities. Forty years ago older people were regarded as among the poorer members of society with nearly half of pensioner households having an income below the poverty threshold of 60 per cent of median household income. That has changed. Today less than a quarter are below the poverty level (Metz and Underwood, 2005: 10). Between 2004/05 and 2014/15, the proportion of retired households in the bottom quintile of UK median income decreased from 45.7 to 39.4 per cent and in the top quintile doubled from 6.1 to 12.6 per cent (Office for National Statistics (ONS), 2016). Incomes of older people have risen relative to younger age groups, particularly since the economic downturn of 2007/08. Since then the median income for retired households has increased in most years with the value rising to $f 21,000$ in $2014 / 15, £ 1,500$ higher than in $2007 / 08$. By contrast, the median income for non-retired households decreased and in 2014/15 was $£ 28,300$, around $£ 900$ below 2007/08 levels 
$(£ 29,200)(O N S, 2016)$. The biggest factor stimulating this change has been the rise in the ability to exploit the private pensions and annuities markets to enhance retirement income. In 1977 the proportion of gross income received by retired households from private pensions was 18 per cent. By 2014/15 this had risen to 43 per cent, significantly shifting both the structural basis of their income and their economic position relative to younger people (ONS, 2016). In addition, people are generating a work-based income for longer. Employment participation rates for those beyond state pension age increased from 8 pe $r$ cent to 11 per cent for males and 7 to 12 per cent for females between 1982 and 2008 (Mayhew, 2009: 34).

Similar large shifts have occurred in the amount of capital owned as age increases. Drawing on data from the English Longitudinal Study of Ageing (ELSA) 2002-2012, Banks et al found that movement along the ageing continuum was accompanied by a greater likelihood of inheritances and greater expectations of future inheritances. For example, of those born in the 1940s, 34 per cent had received an inheritance compared with 30 per cent born in the 1930s and 22 per cent born in the 1920s. The median value of inheritances received is $£ 34,540$ (2013 prices) (Banks et al, 2014: 16). Meanwhile data from the earlier 2002 ELSA study showed that net financial wealth (accumulated savings plus inheritance, excluding housing) increases with age to reach a peak in the mid-60s before declining. In 2003, 85 per cent of all such wealth, $£ 560$ billion, was reported to be owned by the over 50 s (Marmot et al, 2003: Table 3A.7). In 2015, research showed that retirees saved $£ 48.7$ billion peryear (Brancati et al, 2015: 3).

Despite the overall increase in the relative wealth of older people, clearly large inequalities remain within the group itself. There are still 1.6 million (14 per cent) of pensioners living in poverty (with incomes of less than 60 per cent of typical household income after housing costs) of whom 900,000 are in severe poverty (incomes less than half of typical household income) (Age UK, 2016). Some pensioner groups are at greater risk than others. Ethnicity is important: 27 per cent of Asian or Asian British and 24 per cent of Black or Black British are in poverty (Department of Work and Pensions, 2015. See also Bajekla et al, 2004; Moriarty and Butt, 2004). Indeed, the latest Office for National Statistics report on household income 
and inequality observes that there is evidence that inequality rose for retired households but fell for non-retired households in recent years (Office for National Statistics, 2017: section 9). The implication of these income inequalities for the market is that 'there is no such thing as "the older consumer"' but rather a diversity of older consumer groups with quite different patterns of expenditure' (Brancatti et al, 2015: 29).

With increased income and capital comes market power: the capacity to influence existing markets and create new ones through changing patterns of expenditure. As consumers move along the latter stages of the age continuum, so they feel less limited in their market choices. Retired people are 'less constrained by money shortages than those who are not retired': 77.9 per cent said that they never or rarely had too little money for their needs compared to only 59.7 per cent of those not retired (Brancati et al, 2015: 39). The market significance of the relationship between age and increasing wealth is enhanced by weight of numbers. Older people constitute a growing proportion of a growing UK population with the over 65s rising from 15\% in 1984 to a projected 20\% in 2024 (ONS, 2016: Table 4). Life expectancy at birth in the UK has consistently increased, from 70.8 years for males and 76.8 years for females in 1980-1982 to 78.9 years for males and to 82.7 years for females in 2011-2013. Bearing in mind the rise in the UK population from 56.4 million to 64.4 million in the 1984-2014 period, these are significant figures with the over-65 population rising from 8.64 million to 11.59 million.

The impact of these structural changes in the economic base is that the olderconsumer market is large and growing. People over 50 account for 80 per cent of national wealth and nearly 40 per cent of annual consumer spending (HM Government, 2009: 14). Meanwhile the over-60s market is forecast to grow by 81 per cent from 2005 to 2030 , but the 18-59 market by only 7 per cent (Age UK, 2010: 4). Analysis by the Personal Finance Research Centre at Bristol University finds that the 65-plus age group accounts for 20 per cent of the UK consumer population (16-plus), and is expected to rise, so that in 2030 over-65s will account for 25 per cent of the consumer market (Age UK, 2010: 4). 


\section{Ideology and legitimation}

However, as Gramsci would point out, the translation of changes in the economic base of ageing into a challenge to the hegemony of ageing requires an accompanying cultural shift in values to explain and legitimate the nature of the challenge. Merely because economic capacity increases with age does not mean that this capacity will be employed through market choice to forge a new social identity at odds with the prescriptions of the hegemony. It may simply be used to expand markets which reinforce the hegemony of decline. Indeed, this is the more likely option, Gramsci suggests, unless a group of organic intellectuals actively intervene to construct an ideology supportive of the potential changes in the economic base (Gramsci, 1971:328-41). How informative is this theoretical prediction in the case of ageing?

That cultural change associated with the role of olderconsumers has occurred is not in doubt. Research strongly suggests that through its proactive approach to the market the post-war generation has become 'constitutive of the rise of modern consumerism' (Edmunds and Turner, 2002: 4) and characterised by a 'generational habitus of consumption' (Higgs et al : 2007). Accustomed to the life choices provided by affluence, the 'baby boomers' in particular have routinised the construction of identity through lifestyle consumption so that the workplace (and its absence following retirement) is a much reduced influence (Harking and Huber, 2004). In so doing, it is claimed, the baby boom generation 'broke the mould of the modern life course' (Gilleard and Higgs, 2002: 376), rejecting the passivity of previous generations in favour of an active and individualised approach to social identity (Gilleard and Higgs, 2000: 84).

Such an approach to ageing is characteristic of the postmodern which 'involves a shift in patterns of differentiation from the social to the cul tural sphere, from life chances to life styles, from production to consumption'. As a consequence, 'status will not depend on one's location in the society, especially its system of production and reproduction but on one's status accomplishments in the sphere of consumption' (Crook et al, 1992: 133). It leads to the view of a 'third age' advanced by Laslett in A fresh map of life (1989) and Young and Schuller in Life after work (1991) where 'the agentic construction of a life world' is 
achieved through a search for a 'post-working-life' identity, independent of both the state and the productive processes, and the reacquisition of social and cultural capital (Gilleard and Higgs, 2000: 38-40). Whilst British scholars see the third age as a vehicle for enhanced citizenship, in the US the interpretation of the same phenomenon places greater emphasis on the possibilities for personal identity through lifestyle choice (see e.g. Sheehy, 1996). What is common to both, and what others have explored through the concept of 'active ageing', is the view of ageing as a voyage guided by positive choices rather than a passive response to society's definition of ageing (Davey, 2002; Clarke and Warren, 2007). There is of course a 'fourth age' where the foundational aspects of ageing manifest as disability and death may become inescapable, but this does not detract from the counter-hegemonic significance of the third age (Gilleard and Higgs, 200: 197-199).

To this upbeat view of ageing as lifestyle choice can be added the political dimension where, as citizens, older people are prepared to be as proactive in expressing their demand for political products as they are as consumers for economicgoods. The 'grey vote' has become the political equivalent of the 'grey pound', reinforcing the cultural shift from passivity to self-promotion. The voting power of olderpeople is now structurally embedded in the British electoral system with increasing age positively related to voter turnout and the strength of the relationship itself increasing over time (CIPFA, 2015). Bearing in mind that older people are also an increasing proportion of the population, the responsiveness of politicians to their interests and policy demands is an established feature of British politics. Witness for example the attention given by David Cameron to the 'triple lock' policy on the state pension (increases to be by the rate of inflation, average earnings or 2.5 per cent, whichever is the higher) and his promise to ringfence all universal pensioner benefits such as the winterfuel allowance, free bus passes and free TV licences in the run up to the 2015 election. Witness also what happened when Teresa May, having called an election in June 2017, was forced into an ignominious retreat following her short-lived advocacy of a 'double lock' in the 2017 Conservative Manifesto (Conservative Party, 2017: 64). With Labour maintaining support for the triple lock in its manifesto, guaranteeing the winterfuel allowance and free bus passes, promising to 'extend Pension Credit to hundreds of thousands of the most vulnerable women', and claiming that the Conservatives were about 
to 'abandon their commitment to older people' (Labour Party, 2017: 54), the Conservatives found a key component of their core support base dangerously exposed and soon recanted. .Such a combination of consumer and citizen muscle aligned in a common counterhegemonic project suggests the emergence of an important cultural shift. But where are the organic intellectuals to articulate and legitimate it?

The absence of such a group points to a new phenomenon outside the conventional expectations of the Gramscian approach. Rather than an institutionally located vehicle for the production of new values, what we appear to have is a more diffuse situation where the availability of, and engagement with, market opportunities itself stimulates a counterhegemonic movement (see the parallel example of health consumers in the field of stem cell treatments - Salter et al, 2015). This takes us away from the static assumptions of a defined group of intellectual experts as expressed by Gramsci: 'All men are intellectuals, one could therefore say: but not all men have in society the function of intellectuals' (Gramsci, 1971:9). And towards one where, through market interaction in an information rich society, all people may indeed have the function of intellectuals through their individual reflection on, and application of, consumerist values in a particular field to produce changed social relations. Social and cultural capital can be maintained and, indeed, enhanced through the exercise of agentic spontaneity in the cultivation of new forms of identity via market choices.

Successful hegemonies are those capable of recognising, responding to and, if necessary, accommodating the challenge from rising power groups (Germain and Kenny, 1998). In so doing, they engage in what Gramsci terms trasformismo: 'a strategy of assimilating and domesticating potentially dangerous ideas by adjusting them to the policies of the dominant coalition' (Cox, 1983: 166-7). Certainly the state-sponsored hegemony has responded to the challenge of an ideology of ageing based on a narrative of choice and individual empowerment. From the early 2000s onwards, parts of the state showed some public awareness of the market significance of the economic shifts documented in the preceding section. In 2000 the Ageing Population Panel of the Foresight exercise outlined the market opportunities created by older consumers in financial products, health care, preventive 
technology, IT and communications, housing and, particularly leisure and the need for businesses 'to ditch outdated stereotypes about older consumers and focus on the grey pound' (Department of Trade and Industry, 2000: 23). Subsequent reports such as the Department of Work and Pensions' Opportunity age(2005) and Building a society for all ages (2009), the Audit Commission's Olderpeople: independence and well being (2002) and the House of Lords Select Committee on Economic Affairs' report Aspects of the Economics of an Ageing Population (2005) develop these themes further. As authoritative statements by government bodies, the reports constitute official recognition of the market pressures on the hegemonic assumptions of age and powerlessness and the need for the adaptation of the established decline ideology.

In the main, the exercise in trasformismo has been led by the publichealth profession. Its task has been to balance recognition of the validity of the oppositional principles of consumerism and choice with the interest of the blocco storico in maintaining the growth of the pharmaceutical industry and the power of medicine. Central to this task has been the advancement of what has become known as 'the new public health' characterised by the promulgation of policies commonly grouped together as 'health promotion' aimed at the changing of individual behaviour (Petersen and Lupton, 1996). Defined by the WHO's seminal Ottawa Charter as the 'the process of enabling people to increase control over, and to improve, their health' (WHO 1986), health promotion embraces 'empowerment' of the population as a central part of its credo. Influenced by the social gerontology literature on agency, identity and the third age, WHO's ageing empowerment narrative has employed the concept of 'active ageing' as its primary vehicle. Its reports Active ageing: a policy framework (2002), Political declaration and Madrid international plan of action on ageing (2002), and the World report on ageing and health (2015) argued that active ageing should be characterised by 'the process of optimising opportunities for health' through the exercise of choice in the adoption of a 'flexible life course' (WHO, 2015: 5). If empowerment through choice is so valued, the political tension then centres on the question of how "health promotion [can] both promote individual choice and at the same time convince individuals that the experts know best' (Dew, 2012: 53). For the hegemony, the answer is simple: health consumer choice should take place within a saturated information environment 
provided by publichealth professionals: one designed to steer consumer choice in directions that either support or do not challenge the hegemonicinterest. The promulgation of a risk discourse is a keypart of this strategy of control through individual self-regulation.

The 'factors of risk' they [health promoters] identify are distributed throughout the social body to the extent that (responsible) individuals at every turn face the task of having to monitor, regulate and change (that is, refashion) themselves to avoid, modify, control and eliminate behaviours and situations deemed 'risky' (Petersen and Lupton, 1996: 20).

In the UK, the example of the 2010 White Paper Healthy Lives, Healthy People. Our strategy for public health in England neatly encapsulates the dualism inherent in the application of trasformismo to 'active ageing'. On the one hand, it bravely asserts that 'it is simply not possible to promote healthier lifestyles through Whitehall diktat and nannying about the way people should live' and that 'We need a new approach that empowers individuals to make healthy choices' (HM Government, 2010: 2,). On the other, 'central action' is necessary using 'approaches that focus on enabling and guiding people's choices wherever possible', 'changing social norms and default options so that healthier choices are easierfor people to make' and 'nudging people in the right direction' (HM Government, 2010: 30). As a result, the White Paper is confident that 'by using the latest thinking from behavioural science, communities can be better designed to enable active ageing to become the norm rather than the exception' (HM Government, 2010: 47). Through such measures, the objective of empowerment becomes 'obliging people to make the appropriate choices as determined by health experts' (Dew, 2012: 51).

Although some health promotion activities are likely to result in choices that reduce the demand for drugs, others, assisted by the publichealth profession, will produce choices that increase it. In particular, the ever-expanding risk discourse of preventive medicine provides a natural platform for the launching of new drug treatments for a healthy population. Indeed, that is where major new pharmaceutical markets lie. Heath observes that 'As the overall health of a population increases, more money can be made from selling healthcare 
interventions for the healthy majority than for the sick minority' (Heath, 2005: 954). As a result, in developed countries, more resources are now invested in research into the prevention of disease than into its treatment (Freemantle and Hill, 2002). An increasingly common tactic is to present a risk factor as a disease. Referring to the examples of blood pressure and osteopenia, Freemantle and Hill reflect:

It is always difficult to draw a line and dichotomise a continuous variable into normal and abnormal categories, but it is in the interests of the pharmaceutical industry to draw a line that includes as large a population as possible within the range of abnormality. But is it in the interests of the rest of us, either as patients or as citizens? (Freemantle and Hill, 2002: 865)

What remains unresolved is how far this pharmaceutical momentum will be maintained and, even if it is, successful hegemonic adaptation achieved. As the endless debates about statins amply illustrate, the vast information reserves of the internet continually produce scepticism and challenge.

\section{Conclusions}

The politics of ageing is therefore at an interesting juncture with the twin dynamics of hegemony and counter-hegemony finely balanced. As yet there is no indication that the blocco storico of the pharmaceutical industry, medicine and state has been seriously destabilised by the changing economic base of ageing, the impact of the market in enabling the lifestyle choices of older health consumers, and the sensitivity of the state to the expansion of their electoral power. The consumption of drugs continues to increase with age and the medical profession is assiduous in promoting and justifying exciting new pharmaceuticalised definitions of well-being. The hegemonic ageist rhetoric of declining social value, scapegoating and deviancy is still an acceptable feature of broad sheet journalism with Paxman (67), for example, arguing for the removal of the vote for the over 65 s in these terms: 
Some scarcely know what day of the week it is, yet their ballot papers are worth the same as a Cambridge professor's. And politicians know that older pe ople are much more likely to vote - as one put it to me privately, 'there's not much else going on in lots of their lives'. (Paxman, 2015).

Acceptable perhaps, but no longer secure as the popular expression of the hegemonic ideology of ageing.

The challenge has come from a direction not anticipated by Gramscian theory. Instead of an oppositional discourse developed by a particular group of organic intellectuals to exploit changes in the economic base, we find a much more diffuse phenomenon characterised by broad consumerist values of opportunity and choice linked to the expression of new forms of market demand as vehicles for the maintenance and creation of social and cultural capital through agentic spontaneity. It has been a sluggish process not least because potential markets, governed as they were by the youth-oriented values of the hegemony, have been slow to respond to the reformulation of ageing identities inherent in the emergence of the new demand (Metz and Underwood, 2004). Nonetheless, that challenge is now established, generating the very visible political tensions associated with such issues as intergenerational justice, voting power and welfare support where offence is most easily given to the ideol ogical assumptions of decline. The issue of intergenerational justice in particular, for some time labelled as 'victim blaming' (Minkler, 1991), has since Brexit, generated a commission to review issues of fairness and sustainability (Gardiner, 2016; Bangham, Finch $\&$ Phillips, 2018). The supply-side driven hegemony of the blocco storico remains intact, but it is obliged to recognise that its demand-side component is no longer so accepting of the ageing trajectory, nor wholly guided by the benign authority of the medical profession. Institutionalised ageism remains a core feature of welfare provision, particularly in the health service, but its supporting ideology is no longer fully sovereign.

Given the embedded economic base of the hegemony and the expanding market power of the counter-hegemony, the most likely scenario in the near future is the co-existence of both dynamics with periodicideological conflict around particular issues. Neither has the 
ideological power to eliminate the other and neither, in a sense, needs to so long as both can gain economic benefits from the latter stages of the age continuum. Although the exercise in trasformismo through the good offices of the new public health appears to lend the hegemony the initiative in terms of the state-sponsored empowerment of 'active ageing' within professionally defined limits which include preventive medicine, it is not at all clear that self-directed health improvement will remain a controllable phenomenon in an age of internet-driven opportunity. It may simply legitimise and enhance the counterhegemonic search for age identity through market choice.

\section{References}

Abraham, J. (2009a) The pharmaceutical industry, the state and the NHS. In Gabe, J. and Calnan, M. (eds) The New Sociology of the Health Service. London: Routledge.

Abraham, J. (2009b) Sociology of pharmaceuticals development and regulation: a realist empirical research programme. In Williams, S.J., Gabe, J. and Davis, P. (eds) Pharmaceuticals and Society: Critical Discourses and Debates. Oxford: Blackwell.

Abraham, J. and Lewis, G (2002) Citizenship, medical expertise and the regulatory state in Europe, Sociology, 36: 67-88.

Age UK (2010). The golden economy. London: Age UK.

Age UK (2016). Policy Position Paper. Poverty and financial disadvantage (United Kingdom) 
Available at: https://www.ageuk.org.uk/globalassets/age-uk/documents/policypositions/money-matters/ppp poverty and financial disadvantage uk.pdf Accessed $26^{\text {th }}$ October 2017.

Allen JO (2015). Ageism as a risk factor for chronic disease. Gerontologist. 23 January.

Anderson P (2017). The H-word. The peripeteia of hegemony. London: Verso.

Bangham, D., Finch, G. \& Phillips, T. A welfare generation: lifetime welfare transfers between generations. February 2017. intergencommission.org. @resfoundation.

Bajeklal M, Blane D, Grewal I and Karlsen S (2004). Ethnic differences in influences on quality of life at older ages: a quantitative analysis. Ageing \& Society. 24(5): 709-28 Ballard, K., \& Elston, M. A. (2005). Medicalisation: a multi-dimensional concept. Social Theory \& Health $3:$ 228-241.

Banks J, Nazroo J, Steptoe A (2014). The dynamics of ageing. Evidence from the English Longitudinal Study of Ageing 2002-12 (Wave 6). London: Institute of Fiscal Studies.

Beiler A and Morton A (2003). Theoretical and methodological challenges of neo-Gramscian perspectives in international political economy. InternationalGramsci Society. Available at: http://www.internationalgramscisociety.org/resources/online articles/articles/bieler mort on.shtml Accessed 14th March 2016.

Bowling A, Mariotto A, Evans O. (2002). Are older people willing to give up their place in the queue for cardiac surgery to a younger person? Age Ageing. 31(3): 187-92.

Brancati C, Beach, B, Franklin B, Jones M (2015). Understanding retirement journeys: expectations versus realities. London: International Longevity Centre. 
Busfield, J. (2010) 'A pill for every ill': explaining the expansion in medicine use. Social Science and Medicine. 70: 931-41.

Bytheway B and Johnson J (1990) On defining ageism, Critical Social Policy 10 (2) : 27-39.

Centre for Policy on Ageing (2009). Ageism and age discrimination in secondary health care in the United Kingdom. London: Centre for Policy on Ageing.

CIPFA (2015). Political inequality and the power of the grey vote. PublicFinance. 27 August. Available at: http://www.publicfinance.co.uk/opinion/2015/08/political-inequality-andpower-grey-vote Accessed 10 March, 2016.

Clark A (2009). Ageism and age discrimination in primary and community health care in the United Kingdom. London: Centre for Policy on Ageing.

Clarke A and Warren L (2007). Hopes, fears and expectations about the future: what do older people's stories tell us about active ageing? Ageing and Society. 27(4): 465-488 Conrad, P. (2007) The Medicalisation of Society. Baltimore: Johns Hopkins University Press.

Conservative Party (2017). Forward together: our plan for a stronger Britain and a prosperousfuture. London: Conservative Party.

Coren C (2016). Wrinklies have well and truly stitched us up. The Times. 25 June: 28.

Cox R (1983) Gramsci, hegemony and International Relations: an essay in method', Millennium: Journal of International Studies, 12(2): 162-75.

Cox, R.W. (1987) Production, Power and World Order: Social Forces in the Making of History. New York: Columbia University Press. 
Crook S, Pakulski J, Waters M (1992). Postmodernisation: changes in advanced socity. London: Sage Publications.

Davey J (2002) Active ageing and education in mid and later life. Ageing \& Society, 22(1): 95-113Department of Trade and Industry (2000) Foresight: Ageing Population Panel.

The Age Shift: A Consultation Document. London: DTI.

Department of Work and Pensions (2015). Households Below Average Income 1994/5 to 2013/14 London: Department of Work and Pensions. Available at:

https://www.gov.uk/government/uploads/system/uploads/attachment data/file/437246/h ouseholds-below-average-income-1994-95-to-2013-14.pdf Accessed October 22 2017.

Dew, D (2012). The cult and science of public health. New York: Berghahn Books.

Dew, D. Norris, N. Gabe, J. Chamberlain, K. Hodgetts, D. (2015). Moral discourses and pharmaceutical ised governance in households. Social Science and Medicine. 131: 272-279.

Donnelly L (2008) Don't treat the old and unhealthy, say doctors, Daily Telegraph 27 January: 5.

Edmunds J and Turner B (2002). Generations, culture and society. Buckingham: Open University Press.

Ellison A (2016). Doctors prescribe drugs to tackle Britains's gambling epidemic. The Times. 17 February: 1.

Estes CL (1979). The aging enterprise. San Francisco, CA: Jossey-Bass

Estes CL (1986). The ageing enterprise: in whose interests? International Journal of Health Services. 16(2): 243-251. 
Fox, N.J., Ward, K.J. and O'Rourke, A.J. (2007) A sociology of technology govern ance for the information age: the case of pharmaceuticals, consumer advertising and the internet, Sociology. 40: 315-34.

Freemantle N and Hill S (2002). Medicalisation, limits to medicine, or never enough money to go around? British Medical Journal. 324:864-5.

Bangham, D., Finch, G. \& Phillips, T. A welfare generation: lifetime welfare transfers between generations. February 2017. intergencommission.org. @resfoundation.

Germain RD and Kenny M (1998). Engaging Gramsci: international relations theory and the new Gramscians. Review of International Studies 24: 3-21.

Gilleard C and Higgs P (2000). Cultures of ageing. Self, citizen and the body. Harlow: Pearson Education.

Gilleard C and Higgs P (2002). The Third Age: class, cohort and generation. Ageing and Society. 22: 369-82.

Gramsci, A. (1971). In: Hoare, A. and Nowell Smith, C. (Eds.), Antonio Gramsci, Selections from the Prison Notebooks. Lawrence and Wishart, London.

Guthrie, B. Makubate, B. Hernandez-Santiago, V. Dreischult, T. (2015). The rising tide of polypharmacy and drug-drug interactions: population database analysis 1995-2010. BMC Medicine. 13:74 1-10.

Harkin J and Huber J (2004). Eternal youths: how the baby boomers are having their time again. London: Demos. 
Harries C, Forres D, Harvey N, McClelland A and Bowling A (2007). Which doctors are influenced by a patient's age? A multi-method study of angina treatment in general practice, cardiology and gerontology, Quality and Safety in Health Care 16 (1) : 23-27

Harris J (2005) It's not NICE to discriminate, Journalof Medical Ethics 31 (7): 373-375

Haug M and Levin B (1981). 'Practitioner or patient: who's in charge?' Journal of Health and Social Behaviour. 22, 212-29..

Health and Social Care Information Centre (2014a). Prescriptions Dispensed in the Community, Statistics for England, 2003-2013. Available at:

http://www.hscic.gov.uk/catalogue/PUB14414 Accessed 5 April 2016.

Health and Social Care Information Centre (2014b). Health, social care and lifestyles. Available at: http://www.hscic.gov.uk/catalogue/PUB16076/HSE2013-Sum-bklet.pdf Accessed 5 April 2016.

Heath I (2005). Who needs health care - the well or the sick? British Medical Journal. 330: 954.

HM Government (2009). Building a society for all ages. White Paper. Cm 7655. London: Stationery Office.

HM Government (2010). Healthy Lives, Healthy People. Our strategy for public health in England. White Paper. CM 7985. London: Stationery Office.

IMS Institute for Healthcare Informatics (2014). Global outlook for medicines through 2018.

Kearney N, Miller M, Paul J and Smith K (2000) Oncology healthcare professionals' atti tudes toward elderly people, Annals of Oncology 11 (5) : 599-602. 
Kite $M$ and Wagner L. (2002) Attitudes toward older and younger adults. In: Nelson TD, editor. Ageism: stereotyping and prejudice against older persons. Cambridge (MA): MIT Press. 129-61.

Labour Party (2017). For the many, not the few. London: Labour Party.

Law, J. (2006) The Big Pharma. London: Constable and Robinson.

Levy, B. (2009). Stereotype embodiment: A psychosocial approach to aging. Current Directions in Psychological Science, 18 (6): 332-336.

Lloyd-Sherlock P, Ebrahim S, McKee M, Prince M (2015). Institutional ageism in global health policy. British Medical Journal. 354:i4514.

Marmot M, Banks J, Blundell R et al (eds) (2003). Health, wealth and lifestyles of the older population in England: the 2002 English Longitudinal Study of Ageing. London: Institute of Fiscal Studies.

Mayhew L (2009). Increasing longevity and the economic value of healthy ageing and working longer. London: Cass Business School.

Meisner, B. A. (2012). A meta-analysis of positive and negative age stereotype priming effects on behavior among older adults. TheJournal of Gerontology, Series B: Psychological Sciences and Social Sciences, 67 (1): 13-17.

Metz D and Underwood M (2005). Older, richer, fitter. Identifying the customer needs of Britains's ageing population. London: Age Concern.

Moran, M. (1999). Governing the health care state: a comparative study of the United Kingdom, the United States and Germany. Manchester: Manchester University Press. 
Moriarty J and Butt J (2004). Inequalities in quality of life among older people from different ethnic groups. Ageing \& Society. 24(5): 729-53.

Moynihan, R. (2002) Disease-mongering: how doctors, drug companies, and insurers are making you feel sick. British Medical Journal 324 (7342): 886-891.

National Center for Health Statistics (2017). Health, United States, 2016: With Chartbook on Long-term Trends in Health. Hyattsville, MD: National Centre for Health Statistics. Available at: https://www.cdc.gov/nchs/data/hus/hus16.pdf\#094 Accessed 28 ${ }^{\text {th }}$ October 2017.

Office for National Statistics (ONS) (2017). Household disposable income and inequality: financial year ending 2016. Available at:

https://www.ons.gov.uk/peoplepopulationandcommunity/personaland householdfinances/i ncomeandwealth/bulletins/householddisposableincomeandinequality/financialyearending2 016 Accessed $28^{\text {th }}$ October 2017.

Paxman J (2015). Cull the grey vote - it is an affront to democracy. Financial Times. 27 November.

Petersen, A and Lupton D (1996). The new public health: health and self in the age of risk. London: Sage Publications.

Phillipson C(1982). Capitalism and the construction of old age. London: the Macmillan Press.

Phillipson C(1998). Reconstructing old age: new agendas in social theory and practice. London: Sage.

Rajapakse A, Rajapakse S and Playfer J (2008). Age bias in clinical trials of Parkinson's disease treatment, Journal of the American Geriatrics Society 56 (12) : 2353-2354 
Relman AS (1980). The New Medical-Industrial Complex. New England Journal of Medicine. 303 (17): 963-970.

Salter, B. (2004) The New Politics of Medicine. Basingstoke: Palgrave.

Salter B, Zhou Y, Datta S (2015). Hegemony in the marketplace of biomedical innovation: Consumer demand and stem cell science. Social Science and Medicine. 131: 156-63.

Salter C, Howe A, McDaid I, Blacklock B, Lenaghan L and Shepstone L (2011). Risk, significance and biomedicalisation of a new population: Ol der women's experience of osteoporosis screening. Social Science and Medicine. 73: 808-15.

Sheehy G (1996). New passages. London: HarperCollins.

Townsend P (1986). Ageism and social policy. In Phillipson C and Walker A (eds). Ageing and social policy: a critical assessment. Aldershot: Gower.

Wade, R.H. (2002). US hegemony and the World Bank: the fight over people and ideas. Review of International Political Economy. 9(2): 215-243.

Walker A (1980). The social creation of poverty and dependency in old age. Journal of Social Policy. 9: 49-75.

Walker A (1981). Towards a political economy of old age. Ageing and Society. 1(1): 73-94.

Williams, G.A. ( 1960). The concept of 'egemonia' in the thought of Antonio Gramsci: some notes on interpretation. Journalof the History of Ideas 21(4): pp. 586-599.

Williams, S. Martin, P. Gabe, J (2011). The pharmaceuticalisation of society: a framework for analysis. Sociology of Health and IIIness. 33(5): 710-35. 
Wohl S (1984). The Medical-Industrial Complex. New York: Harmony.

World Health Organisation (2015). World report on ageing and health. Geneva: WHO Press.

Wurm, S., \& Benyamini, Y. (2014). Optimism buffers the detrimental effect of negative selfperceptions of ageing on physical and mental health. Psychology \& Health, 29 (7): 832-848. 